\title{
STUDY OF EFFECT OF FRICTION STIR WELDING PARAMETERS ON IMPACT ENERGY OF AA7075-T6
}

\author{
Duong Dinh Hao ${ }^{1,}$, Tran Hung Tra ${ }^{1}$, Vu Cong Hoa ${ }^{2}$ \\ ${ }^{I}$ Department of Engineering Mechanics, Nha Trang University, 02 Nguyen Dinh Chieu St., \\ Nha Trang City, Vietnam \\ ${ }^{2}$ Department of Engineering Mechanics, Ho Chi Minh City University of Technology, \\ 268 Ly Thuong Kiet St., District 10, Ho Chi Minh City, Vietnam
}

*Email:dinhhao@ntu.edu.vn

Received: 29 March 2015; Accepted for publication: 12 September 2015

\begin{abstract}
The influences of the tool rotation speed (denoted $\omega$ ) and the welding speed (denoted $v$ ) on the impact energy at the representative zones in the friction stir welding (FSW) of AA7075-T6 were investigated. Here, the standard V-Notched specimens were applied in which the notches were addressed at the stirred zone (SZ), the heat affected zones (HAZ) in both the advancing side and the retreating side and the mixed zone (MZ). The experimental results showed that, in all cases, the lowest impact energy is located at the stirred zone and that energy seems to be increased from the SZ to the HAZ across the welding. Furthermore, it is also found that the impact energy is decreased when the ratio of rotation speed to welding speed $(\omega / v)$ is increased. The microstructure, the temperature distribution, and the hardness in and around the welded zone were considered and discussed.
\end{abstract}

Keywords: friction stir welding, welding speed, temperature distribution, microstructure, hardness, impact energy.

\section{INTRODUCTION}

Aluminum alloy 7075-T6 has a very high ultimate tensile strength of $572 \mathrm{MPa}$ and yield strength of $503 \mathrm{MPa}$ [1], and is used extensively in the aerospace industry along with others in the AA2xxx series (Fig. 1). They are, however, aluminum alloys which are considered unsuitable for arc welding. This is one of their weaknesses.

In 1991, The Welding Institute (TWI) in the UK invented new technology - "friction stir welding" (FSW) (Fig. 2). This is a welding process executed in the solid state by the heat friction and the application is mainly for non-ferrous metals, especially aluminum and its alloys [2]. This welding technology can overcome weaknesses as well as improve the strength at the 
weld which is essential. Compared to fusion weldings, the friction weld technique possesses several advantages such as high strength, defect free, low distortion, etc. [3].

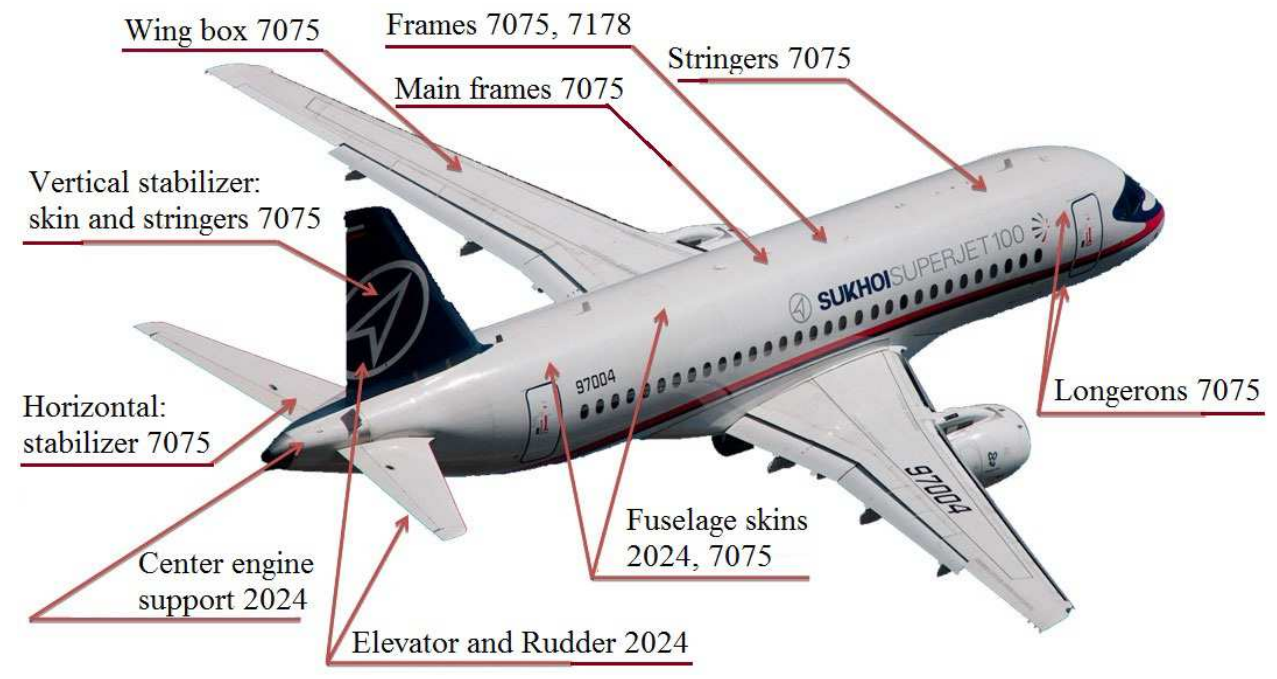

Figure 1. Application AA7075 in structural aeroplane [4].

Since the advantages of FSW to aluminum alloys have become apparent, many researchers have investigated the parameters of this new joining technology, that affect welding qualities. In addition, they are conducting research to find the best regimes to apply.

In order to research the applied abilities of the FSW of AA7075-T6 to the aerospace industry as well as shipbuilding, the $5.0 \mathrm{~mm}$ sheets are fabricated and investigated for the effect of the tool rotation speed and the welding speed on the Charpy impact energy in and around the welded zone, i.e. the stirred zone (SZ), heat affected zones (HAZ) in both the retreating side and the advancing side, and the mixed zone (MZ).

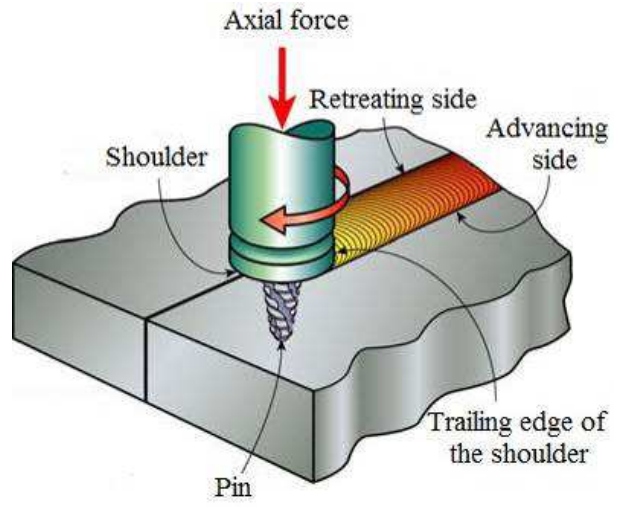

Figure 2. Schematic diagram of friction stir welding [5].

\section{MATERIALS AND EXPERIMENTAL PROCEDURES}

\subsection{Materials}

The chemical composition, and mechanical and thermal properties of the base metal (AA7075-T6) are presented in Table 1 and Table 2, respectively [1].

Table 1. Chemical composition (wt.\%) of the base metal.

\begin{tabular}{|l|l|l|l|l|l|l|l|l|l|}
\hline Element & $\mathrm{Al}$ & $\mathrm{Zn}$ & $\mathrm{Mg}$ & $\mathrm{Cu}$ & $\mathrm{Si}$ & $\mathrm{Fe}$ & $\mathrm{Mn}$ & $\mathrm{Ti}$ & $\mathrm{Cr}$ \\
\hline
\end{tabular}




\begin{tabular}{|c|c|c|c|c|c|c|c|c|c|}
\hline $\begin{array}{c}\text { Base } \\
\text { metal }\end{array}$ & $87.1 \div 91.4$ & $5.1 \div 6.1$ & $2.11 \div 2.9$ & $1.2 \div 2$ & $\begin{array}{c}\text { Max } \\
0.4\end{array}$ & $\begin{array}{c}\text { Max } \\
0.5\end{array}$ & $\begin{array}{c}\text { Max } \\
0.3\end{array}$ & $\begin{array}{c}\text { Max } \\
0.2\end{array}$ & $0.18 \div 0.28$ \\
\hline
\end{tabular}

Table 2. Mechanical and thermal properties of the base metal.

\begin{tabular}{|c|c|c|c|c|c|c|c|c|}
\hline Material & $\begin{array}{c}\text { Ultimate } \\
\text { tensile } \\
\text { strength } \\
(\mathrm{MPa})\end{array}$ & $\begin{array}{c}\text { Yield } \\
\text { strength } \\
(\mathrm{MPa})\end{array}$ & $\begin{array}{c}\text { Elongation } \\
(\%)\end{array}$ & $\begin{array}{c}\text { Hardness } \\
(\text { Rockwell B) }\end{array}$ & $\begin{array}{c}\text { Modulus of } \\
\text { elasticity } \\
(\mathrm{GPa})\end{array}$ & $\begin{array}{c}\text { Poisson's } \\
\text { ratio }\end{array}$ & $\begin{array}{c}\text { Solidus } \\
\left({ }^{\circ} \mathrm{C}\right)\end{array}$ & $\begin{array}{c}\text { Liquidus } \\
\left({ }^{\circ} \mathrm{C}\right)\end{array}$ \\
\hline $\begin{array}{c}\text { Base } \\
\text { metal }\end{array}$ & 572 & 503 & 11 & 87 & 71.7 & 0.33 & 477 & 635 \\
\hline
\end{tabular}

\subsection{Experimental procedures}

In the process of welding (Fig. 3a), the tool geometry that was applied was a scrolled shoulder tool and a truncated cone pin with a pin height of $4.8 \mathrm{~mm}$, the pin diameter of being 5.0 $\mathrm{mm}$ at the middle pin length, and a screw pitch of $1.0 \mathrm{~mm}$ (Fig. 4). The pin was aligned at a tilt angle of $2.0 \mathrm{deg}$. in the plane describing the pin axis and the center weld line (the tilt angle is defined as the angle between the pin axis and the direction perpendicular to the workpieces). The tool tip was kept at a distance of $0.2 \mathrm{~mm}$ from the backing anvil. Various regimes of welding parameters were performed by varying the tool rotation speed (denoted $\omega$, revolving/min) and the welding speed (denoted $v, \mathrm{~mm} / \mathrm{min}$ ).
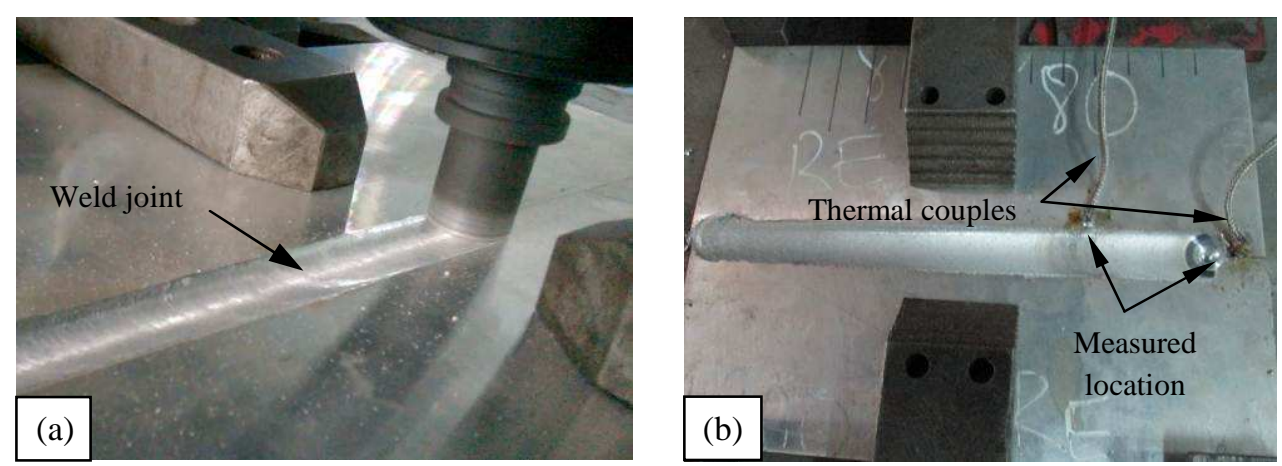

Figure 3. Process of welding (a) and measured temperature (b).

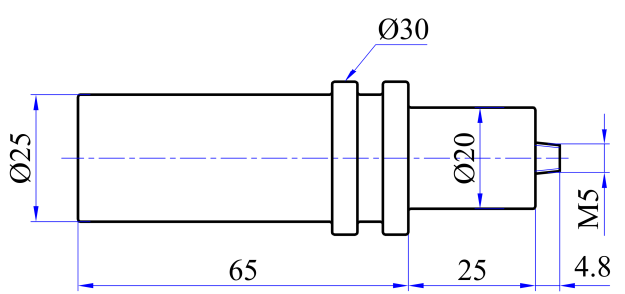

(a)

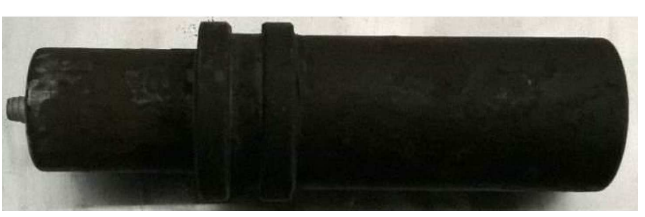

(b)

Figure 4. Dimension (a) and geometry of tool (b) used in this study. 
The temperature distribution is at the end weld center and at the shoulder limit area in both the advancing side and the retreating side $(1.0 \mathrm{~mm}$ far from the shoulder limit line) were measured by thermal couplings attached to the weld surface with a computer software interface during the welding (Fig. 3b). After welding, the samples were sectioned normal to the welding direction, and were then prepared by grinding disks, polished, and finally etched with a reagent: $150 \mathrm{ml} \mathrm{H}_{2} \mathrm{O}, 3 \mathrm{ml} \mathrm{HNO}_{3}, 6 \mathrm{ml} \mathrm{HCl}$, and $6 \mathrm{ml} \mathrm{HF} \mathrm{[6].} \mathrm{The} \mathrm{microstructure} \mathrm{was} \mathrm{observed} \mathrm{by}$ Scanning Electron Microscope. The hardness in and around the welded zone was measured by a Rockwell machine with a ball indenter, $100 \mathrm{~kg}$ loading [7]. The impact test specimens were prepared according to ASTM E023 [8]. There are five specimens that are investigated in this paper. The impact energy was measured in the weld center (SZ), the heat-affected zone (HAZ), and the thermo-mechanically affected zone (TMAZ) or mixed zone (MZ) in both the advancing (AD) and retreating (RE) (Fig. 5). The energy tests were performed by a Charpy impact of Tinius Olsen - Model 84.
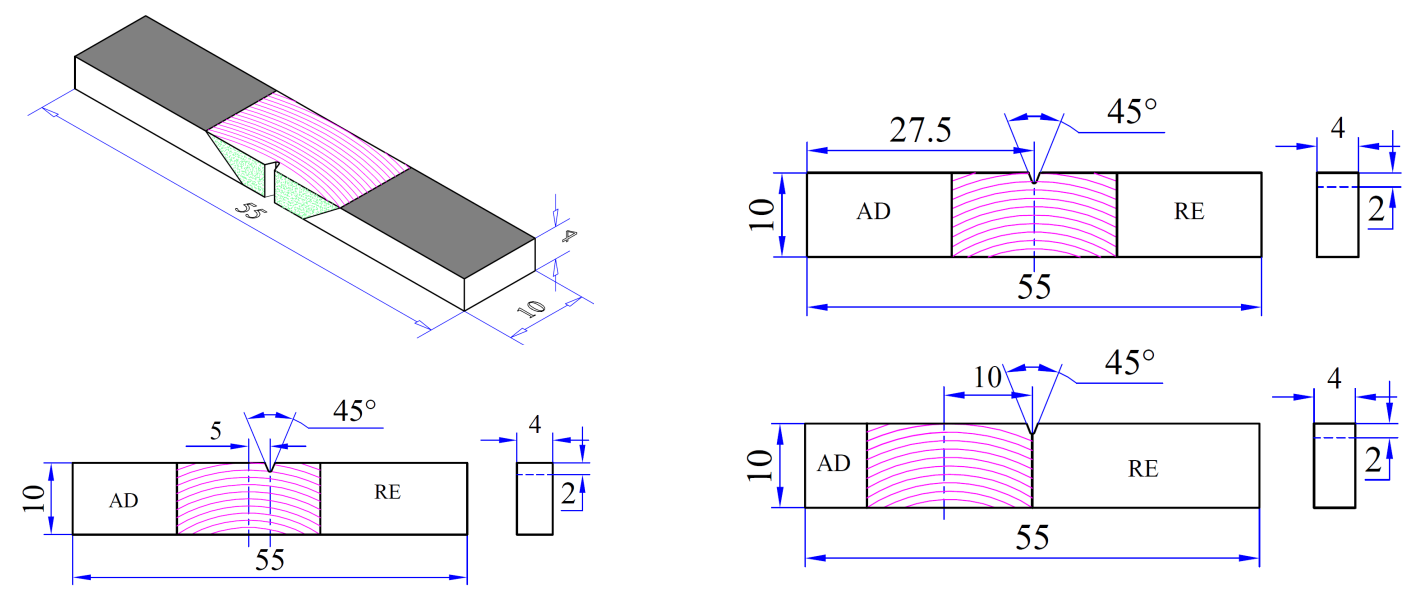

Figure 5. Dimensions of the sub-size specimens used in this work.

\section{EXPERIMENTAL RESULTS AND DISCUSSION}

\subsection{Influence of welding parameters on temperature distribution}

Temperature distribution within and around the stirred zone is important in explaining the mechanical properties of the welds. It directly influences the microstructure of the welds, such as grain size, grain boundary character, coarsening and dissolution of precipitates [9 - 12]. The results of the temperature distribution measured at the heat-affected zone and the end weld center are shown in Fig. 6. The dependence of the peak temperature distribution on the ratio of rotation speed to welding speed $\omega / \mathrm{v}$ is shown in Fig. 7. This figure shows that the temperature increases with an increase in the ratio of rotation speed to welding speed $\omega / v$. This increase can be generated by a combination of friction and plastic dissipation during the deformation of the metal. Therefore, when the ratio of rotation speed to welding speed $\omega / v$ decreases, the friction that is created by the tool shoulder increases. In all cases, the peak temperature distribution was found at the weld center and this temperature was lower than the melting temperature of the base metal as is shown by the dash-lines in which Figure 7. 

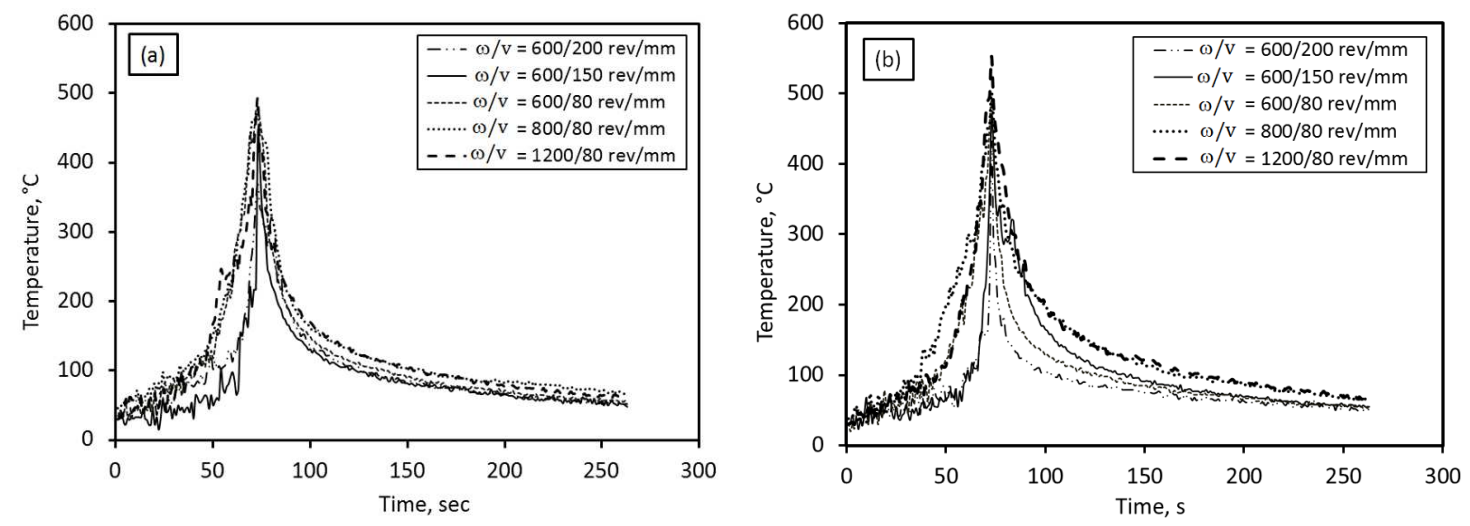

Figure 6. Effect of welding parameters on the thermal cycle at (a) the heat-affected zone and (b) the end weld center.

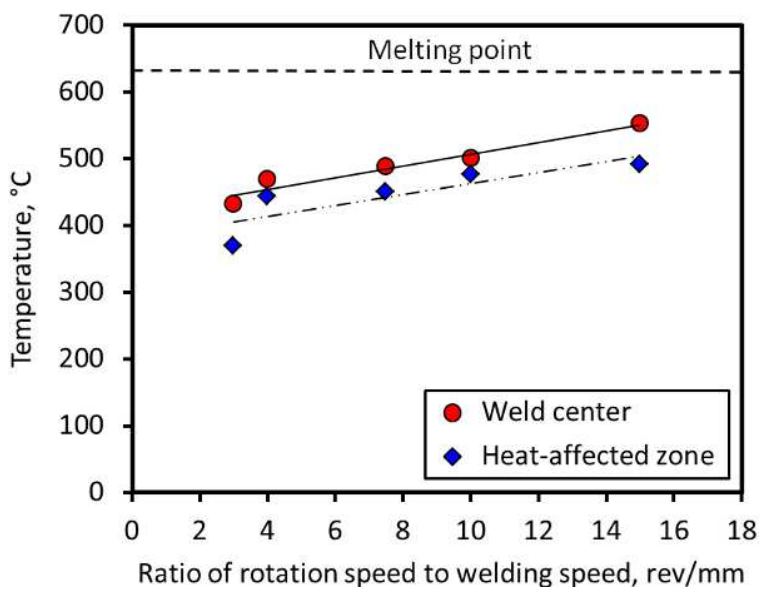

Figure 7. Relation of the peak temperature distribution with the ratio of tool rotation speed to welding speed $(\omega / v)$.

\subsection{Microstructure of the friction stir welded joints}

After polishing, the microstructures of the friction stir welded joint were observed by both the naked eye and the microscope, and some defects were found. These defects occurred in the regimes of $\omega / v=3.0$ and of $15.0 \mathrm{rev} / \mathrm{mm}$ the defect size being approximately $500 \mu \mathrm{m}$ (Fig. 8). From this view, it is reasonable to choose the ratio of tool rotation to welding speed, $\omega / v$, as a welding parameter covering both tool rotation speed and welding speed, and their interaction. The typical microstructure of a FSW AA7075-T6 when fabricated at $\omega / v=10.0 \mathrm{rev} / \mathrm{mm}$ is characterized by the dynamic recrystallization as seen in Fig. 9. In general, grain size in the base metal (about 10-35 $\mu \mathrm{m}$, (region (IV) in Fig. 9d) where the material is far enough from the center of the weld should not be affected by this process. The grain size in the region (I) where the material has undergone a heat cycle without plastic deformation is the same as in the base metal (see region (I) in Fig. 9a). The grain size in region (II) where the material underwent plastic deformation due to the heating friction is created by the shoulder tool, is finer than that in zone (I). The grain size here is about $15-20 \mu \mathrm{m}$ (see region (II) in Fig. 9b). Finally, in the stirred zone (III), the deformed material was the most severe during soldering at the highest heat. Therefore, 
grain size is the smallest (about $5-8 \mu \mathrm{m}$ ) when compared with other regions (see region (III) in Fig. 9c).

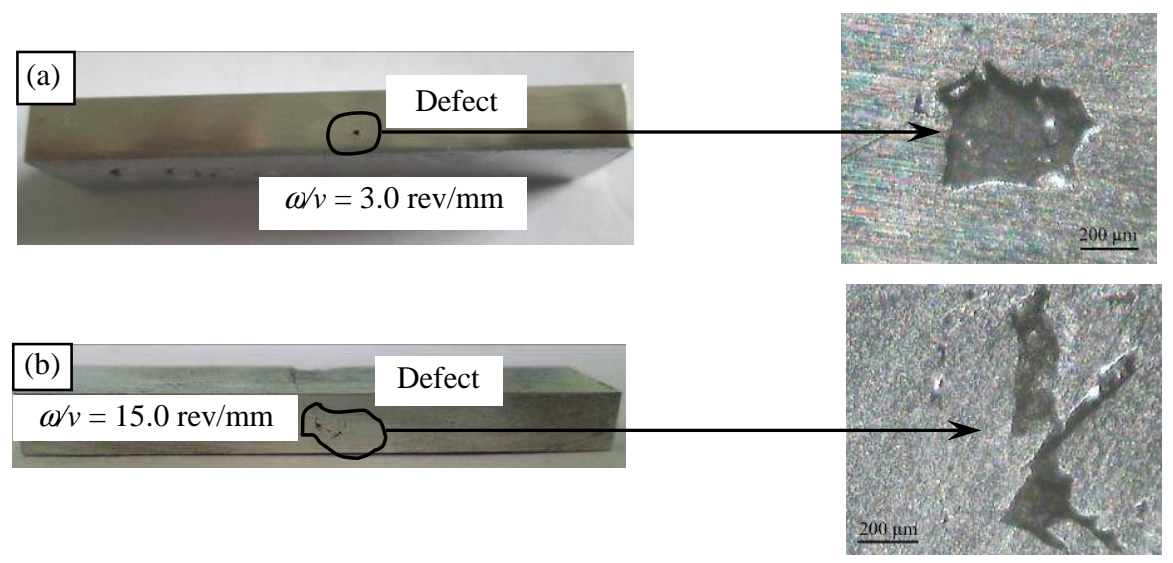

Figure 8. The cross-sectional shape of the weld defect.

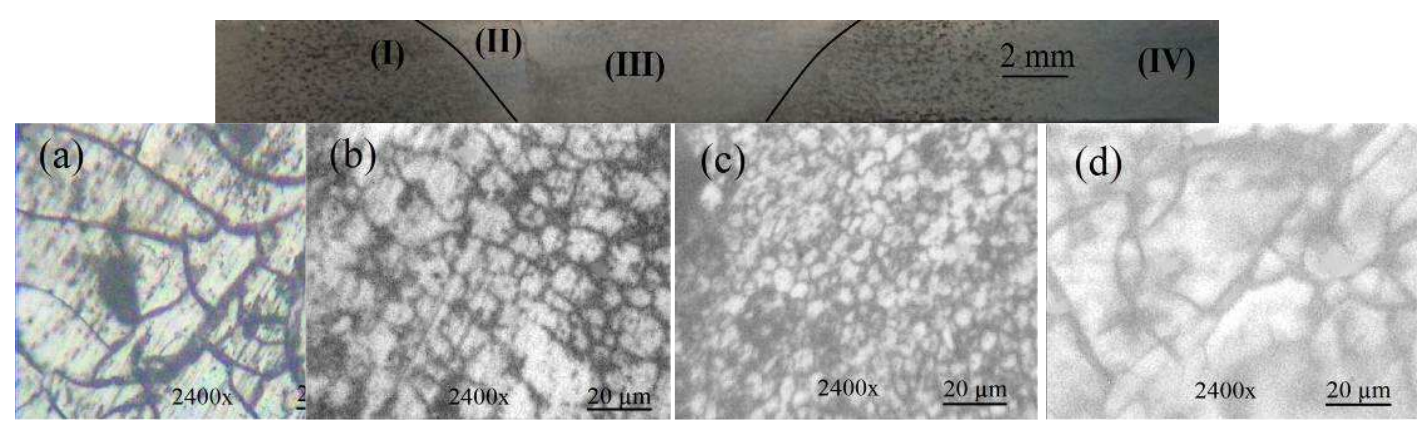

Figure 9. Microstructure in the cross section of FSW at $\omega / v=10.0 \mathrm{rev} / \mathrm{mm}$.

(a) region (I), (b) region (II),

(C) region (III), and (d) base metal (IV).

\subsection{The hardness distribution in the FSW AA7075-T6}

Hardness distributions in the cross section of the FSW at $\omega / v=7.5 \mathrm{rev} / \mathrm{mm}$ were investigated at location 1 and location 2 . The result indicates that the position of the minimum hardness is a heat-affected zone (HAZ) at both location 1 and location 2 (see Fig. 10). Hardness in the stirred zone is higher than in the HAZ but still lower than that of the base metal (located away from the weld center). This may be related to the grain size of the welding zone. The hardness at location 1 is higher than that at location 2 however the difference is not statistically significant. The hardness distributions measured at the middle-line in the cross sections are shown in Fig. 11, as a function of the welding parameter, $\omega / v$. In general, a softened area around the welded zone is observed in all FSWs. The Fig. 11 also shows that the width of the soft zone increases with an increase of $\omega / v$. The softening appearing in and around the welded zone could be related to the dissolution and/or coarsening of the precipitates in this alloy [12]. It was also found, in all cases, that the lowest hardness in the cross section of the FSW is located in the heat affected zone (HAZ) in the advancing side and/or the retreating side, and outside the stirred zone. The fact that the hardness in the stirred zone is higher than that in HAZ might be 
associated with a high density of grain boundaries in the stirred zone or the "Hall Petch Effect" [7].

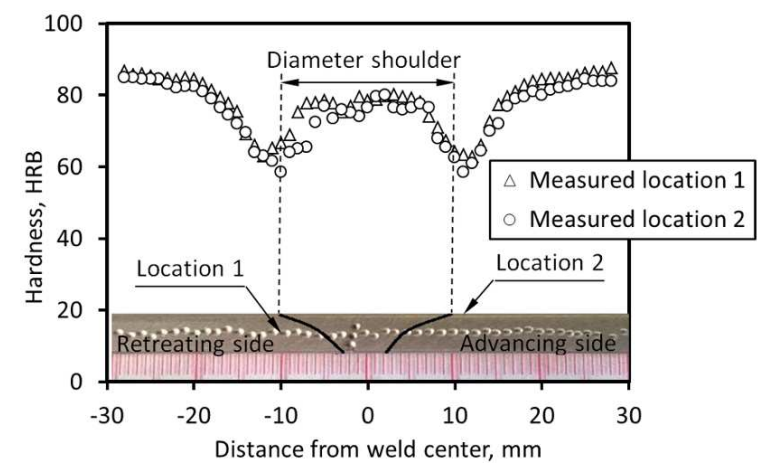

Figure 10. Hardness in the cross section of the FSW at $\omega / v=7.5 \mathrm{rev} / \mathrm{mm}$.

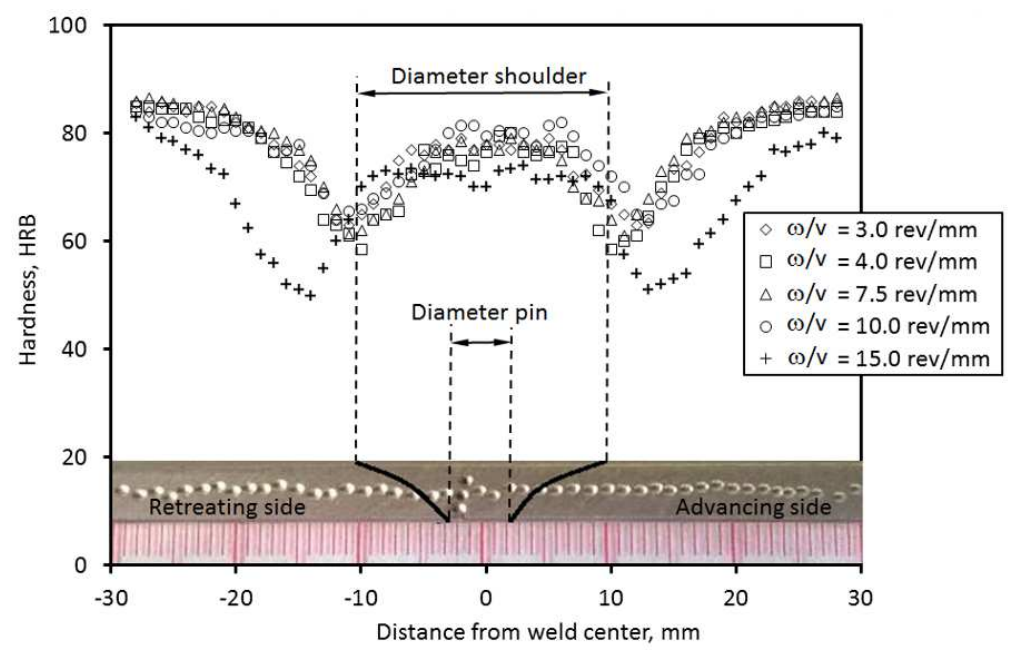

Figure 11. Hardness distributions measured at the middle-line.

\subsection{Influence of welding parameters on impact energy}

Survey result shows that the fracture locations of the weld joints took place inside the notch of specimens except in the case of $\omega / v=15.0 \mathrm{rev} / \mathrm{mm}$ (see Fig. 12). As such, the qualitative weld in this mode was defected and was investigated in Fig. 8.
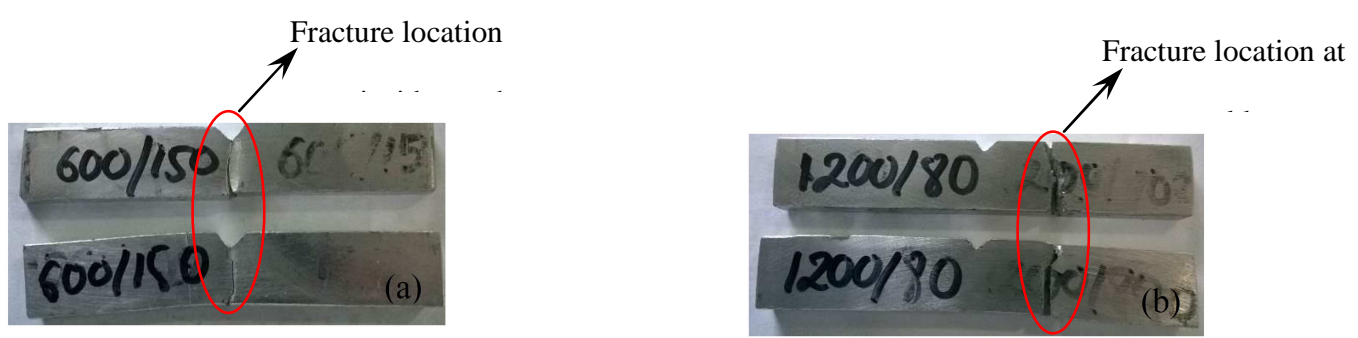

Figure 12. Fracture locations of weld regimes $\omega^{\prime} v=4.0 \mathrm{rev} / \mathrm{mm}$ (a) and $\omega^{\prime} v=15.0 \mathrm{rev} / \mathrm{mm}$ (b). 
The impact energy of the regimes in the weld zones are showed and compared to that of the base metal in Fig. 13. In all cases, the lowest energy value was in the stirred zone (SZ) and this value was smaller than that of the base metal. The impact energy absorption of the weld zone increased when its locations were away from the weld center. This result relates to the input heat and the hardness of the weld zones which are presented in Fig. 6 and Fig. 11, respectively. According to investigations, the stirred zone may be the most brittle in the weld zone due to the greatest hardness. Therefore, the heat-affected zone will be the smallest.

Fig. 14 shows the effect of the tool rotation speed to transverse speed on the impact energy value of FSWs AA7075-T6. Generally, there is a relationship between the ratio of tool rotation speed to welding speed $\omega / v$ and the impact energy. When the ratio of rotation speed to welding speed increased, the impact energy absorption decreased from $5.7 \mathrm{~J}$ to $3.7 \mathrm{~J}$. This result may relate to the input heat and grain size in the weld regimes. When the ratio of rotation speed to welding speed $\omega / v$ increased, the friction that was created by the tool shoulder also increased, therefore, the input heat and grain size in the weld were raised. The reduction of the impact energy here may be associated with the coarser of the grain size in this case [7].
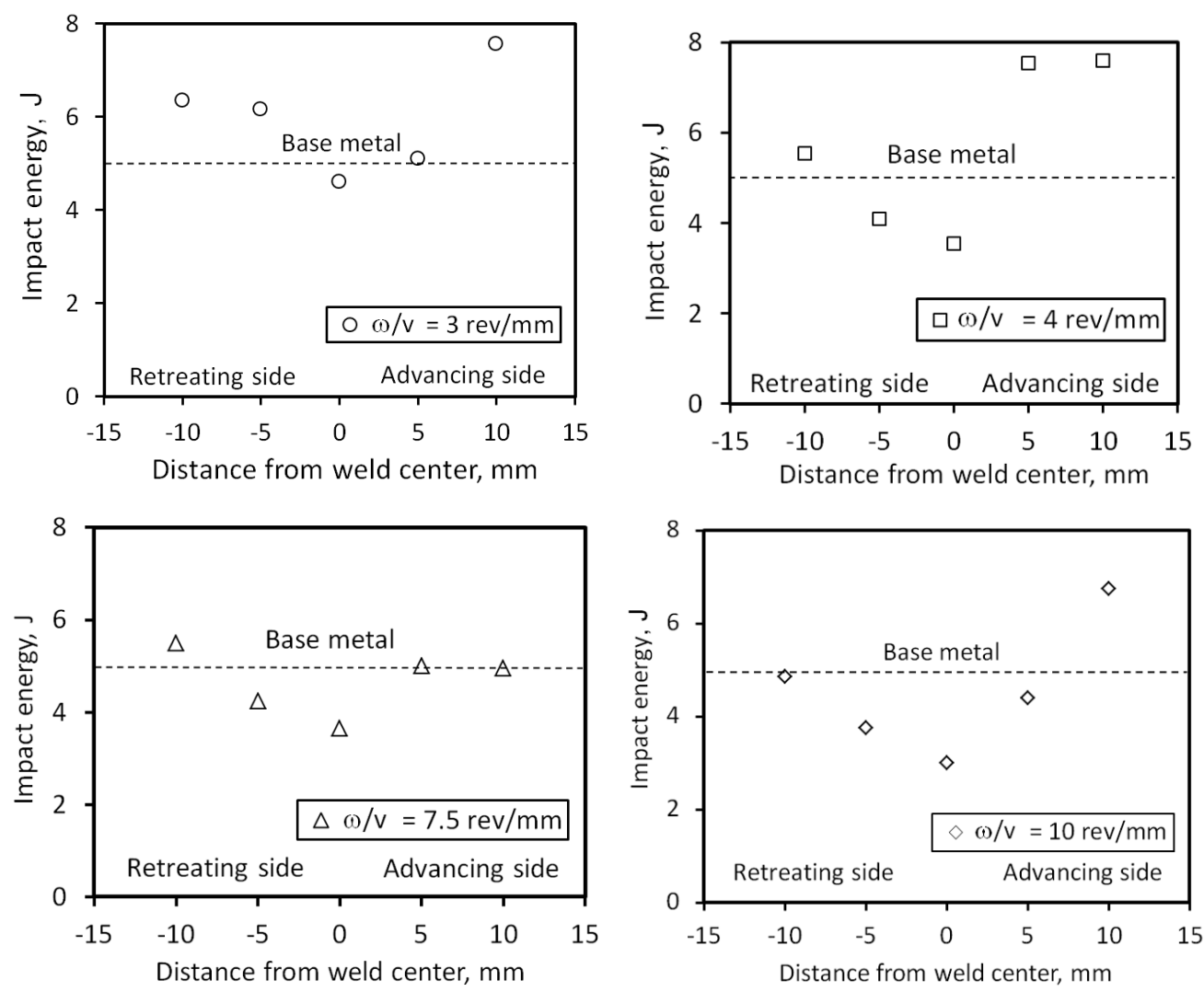

Figure 13. Impact energy absorption in the weld zones. 


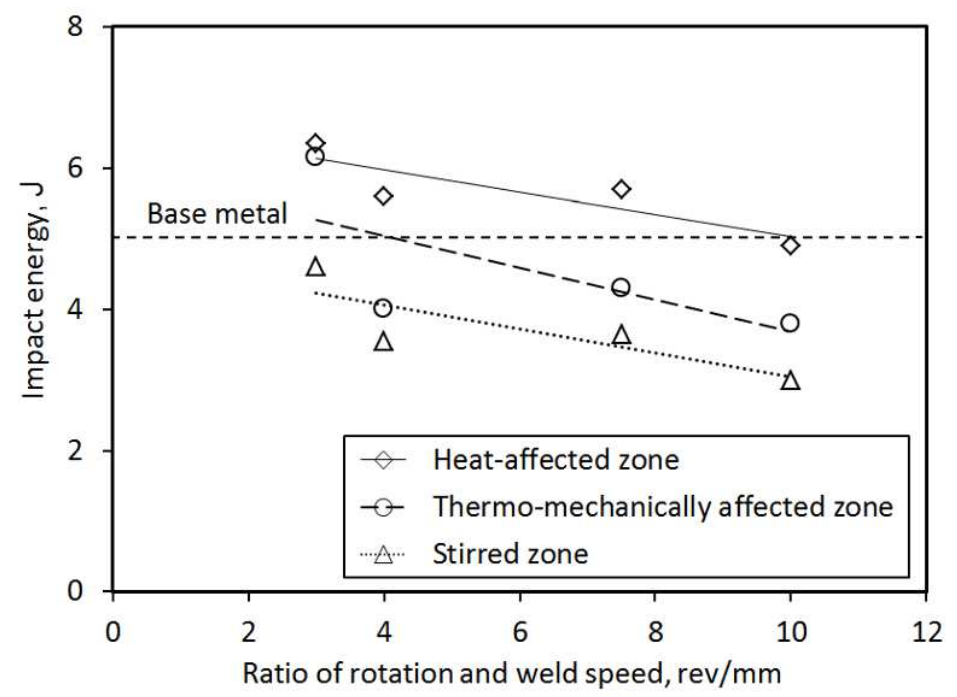

Figure 14. Effect of welding parameters on impact energy.

\section{CONCLUSIONS}

From this investigation the following important conclusions can be derived:

1. Friction stir welds of aluminum alloy AA7075-T6 were successfully fabricated and the effects of welding parameters on its thermal cycles, hardness, and impact energy were investigated.

2. The heat input was found to be proportional to the ratio of tool rotation speed to welding speed $\omega / v$. The weld joint is fabricated successfully when the ratio of rotational speed to welding speed $\omega / v$ is in the range from $4.0 \mathrm{rev} / \mathrm{mm}$ to $10.0 \mathrm{rev} / \mathrm{mm}$.

3. The lowest and highest impact energy absorption of the welding joint are in the stirred zone (SZ) and heat affected zones (HAZ), respectively.

4. The impact energy is decreased when the ratio of rotation speed to welding speed are increased.

\section{REFERENCES}

1. ASM Handbook: Properties and Selection: Nonferrous Alloys and Special-Purpose Materials, ASM International Handbook Committee 2 (1990) 450-462.

2. Rowe C. E. D. and Thomas W. M. - Advances in tooling materials for friction stir welding, (Cedar Metals Ltd, TWI Cambridge), Materials Congress - Disruptive Technologies for Light Metals (2006) 2.

3. Mishra R. S. and Mahoney M. W. - Friction Stir Welding and Processing, ASM International, (2007) 1-5.

4. http://www.altek-mhd.com/en/articles/overview7k2

5. Thomas W. M., Norris I. M., Staines D. G., and Watts E. R. - Friction Stir Welding: Process Developments and Variant Techniques, Paper presented at SME Summit, Oconomowoc Milwaukee USA (2005) 1. 
6. Metals Handbook $8^{\text {th }}$ Edition - Metallography, Structures and Phase Diagrams, American Society for Metals 8 (1973) 124.

7. William D. C. and David G. R. - Materials Science and Engineering $8^{\text {th }}$, John Wiley \& Sons Inc (2010) 175.

8. Standards ASTM - E023: Test Methods for Notched Bar Impact Testing of Metallic Materials (2004).

9. Field D. P., Nelson T. W., Hovanski Y., and Jata K. V. - Heterogeneity of crystallographic texture in friction stir welds of aluminum, Metallurgical and Materials Transactions A: Physical Metallurgy and Materials Science 32 (2001) 2869-2877.

10.Ponda R. W. and Bingert J. F. - Precipitation and grain refinement in a $2195 \mathrm{Al}$ friction stir weld, Metallurgical and Materials Transactions A: Physical Metallurgy and Materials Science 37 (2006) 3593-3604.

11.Oosterkamp A., Oosterkamp L.D., and Nordeide A. - Kissing bond' phenomena in solidstate welds of aluminum alloys, Welding Journal (Miami Fla) 83 (2004) 225.

12.Sato Y. S., Kokawa H., Enomoto M., Jogan S., and Hashimoto T. - Precipitation sequence in friction stir weld of 6063 aluminum during aging, Metallurgical and materials transactions 30 (1999) 3125-3130.

\title{
TÓM TÁ́T
}

\section{NGHIÊN CỨU ẢNH HƯỞNG CỦA THÔNG SỐ HÀN MA SÁT KHUÂY ĐẾN NĂNG LƯợNG VA ĐẬP CỦA HợP KIM NHÔM 7075-T6}

\author{
Dương Đình Hảo ${ }^{1, *}$, Trần Hưng Trà ${ }^{1}$, Vũ Công Hòa ${ }^{2}$ \\ ${ }^{1}$ Bộ môn Co kỹ thuật, Trường Đại học Nha Trang, 02 Nguyễn Đình Chiểu, Nha Trang, \\ Khánh Hòa, Việt Nam \\ ${ }^{2}$ Bộ môn Cơ kỹ thuật, Truờng Đại học Bách khoa Tp. Hồ Chí Minh, 268 Lý Thuờng Kiệt, \\ Quận 10, Tp. Hồ Chí Minh, Việt Nam \\ "Email:dinhhao@ntu.edu.vn
}

Ảnh hưởng của tốc độ quay dụng cụ (kí hiệu $\omega$ ) và tốc độ hàn (kí hiệu v) đến năng lượng va đập ở các vùng của mối hàn ma sát khuấy hợp kim nhôm AA7075-T6 được khảo sát. Trong đó, dạng mẫu thử vết khía chữ $\mathrm{V}$ theo tiêu chuẩn được áp dụng cho vùng khuấy (SZ), vùng ảnh hưởng nhiệt (HAZ) cho cả bên tiến và bên lùi và vùng hỗn tạp $(\mathrm{MZ})$. Kết quả thí nghiệm chỉ ra rằng, trong mọi trường hợp năng lượng va đập thấp nhất nằm ở vùng khuấy và tăng từ vùng $\mathrm{SZ}$ đến vùng $\mathrm{HAZ}$ theo mặt cắt ngang mối hàn. Hơn nữa, kết quả cũng cho thấy rằng, năng lượng va đập giảm khi tỉ số $\omega / v$ tăng. Cấu trúc tế vi, sự phân bố nhiệt độ và độ cứng trong và xung quanh vùng hàn cũng được xem xét và thảo luận.

Tù khóa: hàn ma sát khuấy, tốc độ hàn, sự phân bố nhiệt độ, cấu trúc tế vi, độ cứng, năng lượng va đập. 